\title{
Effects of Some Physicochemical Parameters on Oreochromis Niloticus in Dadin Kowa Reservoir Gombe State Nigeria
}

\author{
*Abubakar U.M., D. M. Umar and Zainab M. Z
}

\begin{abstract}
The physicochemical study of Dadin Kowa reservoir Gombe State Nigeria has been carried out fortnightly over a period of six months (May to October, 2014). Water samples were collected using $250 \mathrm{ml}$ sampling bottles and brought to the laboratory for analysis. Only temperature and transparency were determined insitu. There were no significant difference $(\mathrm{P}>0.05)$ in all the parameters within various months and all the parameters were almost within the tolerable limit for supporting aquatic life. Oreochromis niloticus were sampled by the local fishermen at the landing sites using various mesh sizes of gillnet $(2.0,2.5,3.0 \mathrm{~cm})$. Laboratory measurements were conducted to determine the length and weight of the fish and this information were used to determine the condition factor of the fish. All fish were in good condition as they have condition factor values up to 1 and above. Regulation of the smaller mesh sizes and number of fishermen fishing at a time is recommended as the physicochemical parameters were within the tolerable limits.
\end{abstract}

Keywords - Physicochemical, parameters, Oreochromis niloticus, Dadin kowa, Dam.

\section{INTRODUCTION}

$\mathrm{W}^{\mathrm{s}}$ ATER is a universal and the most vital solvent essential to the existence of all living organisms particularly man (Adeneyi, 2004). Water as an important natural resource influences human settlement patterns, agricultural activities and siting of industries (Nwaugo, et al., 2006). Incidentally in wealth-generating processes, water is a victim of dumping of wastes which degrade the water for other uses (Trouba, 2002). Increase in industries, especially small and medium scale, has its own share of waste generation and disposal problem (Ajiwe et al., 2000). The interactions of both physical and chemical properties of water play a significant role in the composition, distribution and abundance of aquatic organisms. Apart from these, it gives an insight in to the relationships between organisms and their environment and can be used to determine water quality, and productivity of the water body (United Nation Environment Programme, 2006).

Water abstraction for domestic use, agriculture production, industrial production, power generation, and forestry practices can lead to deterioration in water quality that impact not only aquatic organisms, but also the availability of safe water for human consumption (UNEP, 2006). Chronic exposure of aquatic organisms to environmental pollutants

Department of Biological Sciences Gombe State University P. M. B. 127 Gombe, Gombe State. with possible effects on growth and reproduction are important considerations of fish farmers (Lamai, et al., 1999).

The physico-chemical study of water could also help in understanding of the structure and function of a particular water body in relation to its inhabitant. The chemical elements found in water have an effect on biological processes which lead to interconversion of energy, production of organic materials and ultimately to production of aquatic resources such as fisheries and other biological components found in water ecosystem (Mustapha, 2003). The proper balance of physical, chemical and biological properties of water in lakes, ponds, reservoirs, and rivers is an essential ingredient for successful production of fish and other aquatic resources. The presence or absence of a particular chemical element in a water body might be a limiting factor in the productivity of such water body (Mustapha and Omotosho, 2005).

Water pollution occur when a body of water is adversely affected due to addition of large amount of materials to the water, when it is unfit for its intended use, its considered polluted (Poppe and Hurt, 1997).

The aim of this study is to assess some of the physicochemical parameters and relate it to general well being of Oreochromis niloticus in Dadin Kowa Dam.

\section{MATERIALS AND METHOD}

\section{A. Study Area}

Dadin Kowa Dam is located $5 \mathrm{~km}$ North of Dadin Kowa village (about $37 \mathrm{~km}$ from Gombe town, along Gombe-Biu road) in Yamaltu Deba local Government Area of Gombe State. The area lies within longitude 11o 30' E and 11o $32^{\prime} \mathrm{E}$, and Latitude $10 \mathrm{o} 17^{\prime}$ and $10 \mathrm{o} 18^{\prime} \mathrm{N}$ of the equator (UBRDA, 1980). The Dam is part of River Gongola; its drainage basin is situated in North-Eastern Nigeria, with water capacity of 800million cubes and surface area of 300kilometer square.

\section{B. Physicochemical Sampling}

Water samples were collected from the three stations forthrightly over a period of six months (May-October, 2014). Sampling bottles of $250 \mathrm{ml}$ capacity were used; the bottles were rinsed before being filled with water for physicochemical analysis in the laboratory. Only temperature and transparency were determined in situ.

Temperature readings (water and air) were measured using mercury in-glass thermometer. Transparency was 
measured as described by Sterling (1985) using secchi disc depth. The $\mathrm{pH}$ of the water was determined using electronic digital temperature $\mathrm{pH}$ meter (model 3150 Jenway). Electric conductivity was determined as described by (Golterman, et al., 1978); using portable HANA electronic conductivity meter (model: EC 215). Dissolved Oxygen and Alkalinity were determined using Jenway AquaGem water analyzer (model: 4510). Each parameter measured has its module and tablet that were used for sample preparation before taking the sample concentrations.

\section{Fish Sampling}

Oreochromis niloticus was sampled using gillnets of different mesh sizes $(2.0,2.5$ and $3.0 \mathrm{~cm})$ and transported to the laboratory for measurement. Standard length and weight of the fish were measured as described by Olatunde, (1983). Condition factor $(\mathrm{K})$ was determined using conventional formula described by Le Cren (1951).

$$
\begin{aligned}
& \mathrm{K}=\frac{\mathrm{W}^{*} 100}{\mathrm{~L}^{3}} \\
& \text { Where: } \\
& \mathrm{K}=\text { Condition factor } \\
& \mathrm{W}=\text { Weight in grams } \\
& \mathrm{L}=\text { Standard length in } \mathrm{cm} \cdot
\end{aligned}
$$

\section{RESULTS}

The lowest mean water temperature value of $26^{\circ} \mathrm{c}$ was recorded in the month of August, while the highest temperature value of $29^{\circ} \mathrm{c}$ was recorded in the months of June and July (Table 1). Highest transparency value of $11.4 \mathrm{~cm}$ was recorded in the month of June, where the lowest value of $8 \mathrm{~cm}$ was recorded in the month of August (Table 1). Highest $\mathrm{pH}$ value of 8.0 was recorded in the month of May and its lowest value of 6.38 in the month of October (Table 1). Conductivity recorded its lowest value of $21 \mu \mathrm{s} / \mathrm{cm}$ in the month of May and the highest value of $62 \mu \mathrm{s} / \mathrm{cm}$ was recorded in the month of June (Table 1). The lowest dissolved oxygen value of $4.9 \mathrm{mg} / \mathrm{l}$ was recorded in the month of May and the highest value of $7.3 \mathrm{mg} / \mathrm{l}$ was recorded in the months of July and October. Alkalinity recorded its lowest value of $79 \mathrm{mg} / \mathrm{l}$ in the month of August and the highest value of $81 \mathrm{mg} / 1$ in the month of July (Table 1).

The lowest condition factor value of 1.02 was recorded in the month of September, while the highest condition factor value of 2.00 was recorded in the month of July (Table 2).

Temperature correlated positively with $\mathrm{pH}$ and negatively correlated with dissolved oxygen and alkalinity. Transparency correlated positively with $\mathrm{pH}$, dissolved oxygen and alkalinity. $\mathrm{pH}$ positively correlated with alkalinity. Conductivity negatively correlated with alkalinity (Table 3)

\section{Discussion}

Water temperature fluctuated between $26^{\circ} \mathrm{c}$ to $29^{\circ} \mathrm{c}$ throughout the period of the study which fall within the normal range of $8-30^{\circ} \mathrm{c}$ that fish adopt in the tropics (Alabaster and Lioyd, 1980). Transparency ranges from 8.0 to $11.4 \mathrm{~cm}$, the highest value of 11.4 in the month of June might be attributed to the onset of the rainy season which is related to increase in debris load by water run-off. Its agrees with Abubakar et al., (2006) who reported that reduced activity and lack of rains accounted for higher transparency. Abubakar (2006) also reported that suspended materials can clog fish gills, reducing resistance to diseases and growth rate. The monthly mean variation of the $\mathrm{pH}$ values ranged from 6.38 to 8.0 . The recorded values fall within the recommended values of 6-9 in most tropical natural water (ACTFR, 2002). Boyd and Lichkoppler, (1979) also reported pH values of 6-9 as ideal for supporting aquatic life including fish. Mean conductivity values ranged from $21-62 \mu \mathrm{s} / \mathrm{cm}$ which fall within the recommended values of $10-1000 \mu \mathrm{s} / \mathrm{cm}$ by (ACTFR, 2000). Sterling (1985) reported that acidic $(\mathrm{pH}<4.5)$ or alkaline $(\mathrm{pH}$ $>8$ ) waters have appreciable higher conductivity values. Dissolved oxygen values ranged from $4.9-7.34 \mathrm{mg} / \mathrm{l}$ Its falls within the recommended values of Kolo and Tukura (2007) who reported that many species of fish can survive in dissolved oxygen concentrations well below $6 \mathrm{mg} / \mathrm{l}$. The alkalinity of ranged between $79-81 \mathrm{mg} / \mathrm{l}$ during the period of the study. Kolo and Yisa (2000) reported alkalinity values of $84-128 \mathrm{mg} / \mathrm{l}$. Sterling (1985) recommended alkalinity values of $50-300 \mathrm{mg} / \mathrm{l}$ for freshwater fish culture.

The condition factor in this study ranges from $1.02-2.00$ which agrees with Lagler (1952) who reported that the condition factor values are not constant for individual species or populations, but is subject to wide variations. The condition factor should be equal to 1.0 , while $<1$ or $>1$ indicate below and average conditions respectively. Wade (1992) stated that

\begin{tabular}{|c|c|c|c|c|c|c|c|}
\hline \multirow[t]{2}{*}{ Parameters } & \multicolumn{6}{|c|}{ Months } & \multirow[b]{2}{*}{ Mean } \\
\hline & May & June & July & August & September & October & \\
\hline Tempt $\left({ }^{\circ} \mathrm{c}\right)$ & 28.0 & 29.0 & 29.0 & 26.0 & 27.0 & 28.0 & 27.83 \\
\hline $\begin{array}{l}\text { Transparency } \\
(\mathrm{cm})\end{array}$ & 10.0 & 11.4 & 9.4 & 8.0 & 9.2 & 10.0 & 9.66 \\
\hline $\mathrm{pH}$ & 8.0 & 7.4 & 6.7 & 7.0 & 6.74 & 6.38 & 7.04 \\
\hline $\begin{array}{l}\text { Conductivity } \\
(\mu \mathrm{s} / \mathrm{cm})\end{array}$ & 21.0 & 62.0 & 39.0 & 42.0 & 32.0 & 30.2 & 37.7 \\
\hline $\mathrm{DO}(\mathrm{mg} / \mathrm{L})$ & 4.9 & 5.2 & 7.3 & 6.0 & 6.5 & 7.3 & 6.2 \\
\hline $\begin{array}{l}\text { Alkalinity } \\
(\mathrm{mg} / \mathrm{l})\end{array}$ & 80.06 & 80.19 & 81.00 & 79.00 & 80.16 & 80.02 & 80.13 \\
\hline
\end{tabular}
condition factor greater or equal to 1.0 is good.

TABLE I

MEAN MONTHLy VARIATION OF PHySiCOCHEMICAL PARAMETERS OF DADIN KOWA DAM

TABLE II

MEAN CONDITION FACTOR OF OREOCHROMIS NILOTICUS IN DADIN KOWA DAM

\begin{tabular}{llllllll}
\hline & \multicolumn{7}{c}{ Months } \\
\hline & May & June & July & Aug & Sept & Oct & Mean \\
No. of fish & 20 & 20 & 20 & 20 & 20 & 20 & 20 \\
Weight (g) & 45.0 & 48.0 & 46.0 & 40.0 & 42.0 & 48.0 & 44.83 \\
Length (cm) & 16 & 14 & 13.2 & 15.0 & 16.0 & 15.4 & 14.93 \\
Condition factor & 1.09 & 1.75 & 2.00 & 1.20 & 1.02 & 1.30 & 1.39 \\
(K) & & & & & & & \\
\hline
\end{tabular}


TABLE III

CORRELATION MATRIX OF THE PHYSICOCHEMICAL PARAMETERS OF DADIN KOWA DAM

\begin{tabular}{lcccccc}
\hline & Temperature & Transparency & $\mathrm{pH}$ & Conductivity & $\mathrm{DO}_{2}$ & Alkalinity \\
\hline Temperature & 1 & & & & & \\
Transparency & .03 & 1 & & & & \\
$\mathrm{pH}$ & $.57^{*}$ & $.71^{*}$ & 1 & & & \\
Conductivity & .28 & .37 & -.43 & 1 & & \\
Dissolved $\mathrm{O}_{2}$ & $-.83^{*}$ & $.73^{*}$ & -.03 & .274 & 1 & \\
Alkalinity & $-.81^{*}$ & $.88^{*}$ & $.74^{*}$ & $.79^{*}$ & .17 & 1 \\
\hline
\end{tabular}

*Correlation is significant at 0.05 level (2tailed).

\section{REFERENCES}

[1] Adeniyi, I. F. (2004). The concept of water quality In: Ife environmentalist, official Bulletin of Nigerian Society for environmental management (NISEM) O. A. U., 1(1):2.

[2] Abubakar K.A. (2006): A Study of aspect of productivity and stock status of Oreochromis niloticus and Clarias gariepinus in Lake Geriyo, Yola, Adamawa State. Phd. Thesis: F. U. T. Yola.

[3] Abubakar K. A., Haruna A.B. and Ladu B. M. B. (2006). An assessment of physico-chemical parameters and productivity status of Lake Gerio, Yola, Adamawa State, Nigeria.African Journal of Environmental Science and Technology vol. 2(7), pp. 185-196.

[4] ACTFR (2002). Water quality for sustainable Agriculture NRM wet Tropics. Australian centre for tropical fresh water research.

[5] Ajiwe, V. I. E., Nwanbuike, B. O., Onochie C. C., and Ajibola, V. O. (2000). Surface water pollution by effluents from industries in Nnewi, area, Nigeria. Journal of Applied sciences 3(3): 1266-1267.

[6] Alabaster, J. S., and R. Lioyd (1980): Water Quality for freshwater fish. FAO and Butter Worths, London. 29.

[7] Boyd, C. C. and Lichtoppler, F (1979): Water quality management in pond fish culture. International centre for Aquaculture expiremental stations, Auburn University USA.Pp 20.

[8] Golterman H. L., Clymo, R. S and Ohnstad, M. A. M (1978): Methods for physical and chemical analysis of freshwater. I B. P. Handbook No. $82^{\text {nd }}$ edition, Oxford. Blackwell.

[9] Kolo, R. J. (1996): The assessment of physico-chemical parameters of Shiroro Lake and its major tributaries. Proceedings of 1996 FISON Conference. Pp 260-268.

[10] Kolo, R. J. and M. Yisa (2000): Preliminary Baseline assessment of the Water Quality of river Niger. Federal College of fisheries Technology.New Bussa Nigeria. Vol. 2: 99-106.

[11] Kolo, R. J. and Tukura, M. D. (2007):Aspects of limnological studies of Tagwai Dam, Niger State Nigeria. Journal of Aquatic Sciences 22(1): 27-32.

[12] Lamai, S. L., Warner, G. F. and Walker, C. H. (1999). Effect of deldrin on life stages of the African catfish, Clarias gariepinus (Burcell, 1822). Ecotoxicology and environmental safety, 42: 22-29. http://dx.doi.org/10.1006/eesa.1998.1723

[13] Mustapha M. K. and J. S. Omotosho (2005).An assessment of the physico-chemical properties of Moro Lake, Kwara State, Nigeria.African Journal of Applied Zoology and Environmental Biology.2005, vol 7, 73-77.

[14] Nwaugo, V. O., Obiekezie S. O., Onyeagba, R. A., Okereke, J. N., and Udebuani, A. (2006). The physico-chemical investigation of Amicol Lake in Ivo area of Ebonyi State, Nigeria. World Journal of Biotechnology, 7: 1055-1061.

[15] Stirling H. P. (Ed) 1985. Chemical and Biological methods of water quality Analysis for Aquaculture, university of Stirling, printed and made in Great Britain 119pp.

[16] Trouba, D. (2002). Why balance water use?. Journal of Stockholm water front 2: 2 Stockholm Sweden.

[17] Upper Benue River Basin Development Authority (UBRDA) 1980). Dadin-Kowa Resettlement Project, Draft final report. Vol. 2.

[18] Mustapha M. K. (2003). A pre-impoundment study of the limnochemical conditions of Oyun Lake in Ilorin, Kwara State, Nigeria.African Journal of Applied Zoology and Environmental Biology. 5, 44-48.
[19] Wade, J. W. (1985): Limnological and trace element studies in relation to primary productivity in two marine lakes. M.Sc. Thesis. University of Jos, Nigeria, 205pp.

[20] United Nation Environment Programme (UNEP, 2006): Water quality for ecosystem and Human Health.

[21] Poppe, W. and Hurt, R. (1997) : Water pollution, Water quality INST. 39-43Pp.

[22] Olatunde, A. A. (1983): The Length-weight relationship and diets of Clarias in Zaria. Proceeding of the $3^{\text {rd }}$ Annual conference of FISON, Maiduguri 183-192.

[23] Le Cren E. D. (1951): The length- weight relationship and seasonal cycle in gonad weight and condition in the Perch (Percufluviatilis). Anion. Ecol. 20: 201-219.. http://dx.doi.org/10.2307/1540 